\title{
Directe horizontale werking van primair Unierecht in de praktijk
}

\author{
Een illustratie aan de hand van de verdragsbepalingen inzake het vrije verkeer \\ van goederen
}

\author{
Mr.drs. T.S. Hoyer*
}

\begin{abstract}
1 Inleiding
Het Asserdeel 3-I* van de hand van Hartkamp beschrijft de invloed van het Unierecht op het Nederlandse vermogensrecht. ${ }^{1}$ Het is voor de praktijkjurist echter niet steeds duidelijk hoe hij deze theorie in de praktijk kan gebruiken. Aan de hand van een beschrijving van de invloed van de verdragsbepalingen inzake het vrije verkeer van goederen op privaatrechtelijke rechtsverhoudingen maak ik in deze bijdrage inzichtelijk welke mogelijkheden het Unierecht de praktijk biedt. Hiervoor gebruik ik de volgende fictieve casus, die gebaseerd is op de staking van de Duitse sluiswachters in de zomer van 2013. ${ }^{2}$
\end{abstract}

Op initiatief van drie vakbonden staken de sluiswachters in Nederland. De vakbonden verzetten zich tegen een aangekondigde reorganisatie binnen Rijkswaterstaat, waarbij een groot deel van de banen dreigt te worden geschrapt. De vakbonden spreken af om de sluizen onbediend te laten, waardoor binnenvaartschippers die goederen vanuit of door Nederland naar andere EU-landen vervoeren, te maken hebben met lange wachttijden. De schippers stellen dat de acties in strijd zijn met het Unierecht, in het bijzonder hun recht op vrij verkeer van goederen (art. 34 en 35 van het Verdrag betreffende de werking van de Europese Unie; VWEU).

Aan de hand van de hiervoor geschetste casus zet ik uiteen welke stappen men moet zetten om te bepalen welke invloed de verdragsbepalingen betreffende het vrije verkeer van goederen hebben op privaatrechtelijke rechtsverhoudingen. Daarbij

\footnotetext{
Mr. drs. T.S. Hoyer studeerde Onderneming \& Recht en Biomedische Wetenschappen aan de Radboud Universiteit Nijmegen. De auteur dankt prof. mr. C.H. Sieburgh en mr. R.W.E. van Leuken voor hun waardevolle commentaar op eerdere versies van deze bijdrage.

1. Asser/Hartkamp 3-I*, Deventer: Kluwer 2011.

2. Einde staking Duitse sluiswachters in zicht, NU.nl 9 september 2013, $<$ www.nu.nl/economie/3570674/einde-staking-duitse-sluiswachters-inzicht.html>; Binnenvaartschippers lijden onder Duitse staking, NU.nl 22 augustus 2013, <www.nu.nl/ondernemen/3556287/binnenvaartschippers-lijden-duitse-staking.html>; Staking Duitse sluiswachters uitgebreid, NU.nl 11 augustus 2013, <www.nu.nl/economie/3547786/ staking-duitse-sluiswachters-uitgebreid.html >; Schippers hekelen acties Duitse sluiswachters, NU.nl 5 augustus 2013, <www.nu.nl/economie/ 3543155/schippers-hekelen-acties-duitse-sluiswachters.html>.
}

ga ik niet alleen in op de huidige stand van de rechtspraak van het Hof van Justitie van de Europese Unie (hierna: het Hof), maar probeer ik ook aan te geven hoe deze rechtspraak zich zal gaan ontwikkelen.

In paragraaf 2 behandel ik de vraag of het Unierecht zich verzet tegen de acties van de vakbonden. Daartoe ga ik eerst in op de doorwerking van het Unierecht in de Nederlandse rechtsorde en op de vraag of het vrije verkeer van goederen directe horizontale werking heeft. Daarna beantwoord ik in paragraaf 3 de volgende drie casusvragen:

1. Is de afspraak tussen de vakbonden om te gaan staken nietig?

2. Hebben de ladingbelanghebbenden een recht op schadevergoeding?

3. Dient de rechter de nietigheid van de afspraak tussen de vakbonden ambtshalve te beoordelen, indien door partijen op de nietigheid geen beroep is gedaan?

\section{Doorwerking van Unierecht in privaatrechtelijke rechtsverhoudingen}

In de arresten Costa/ENEL en Simmenthal heeft het Hof bepaald dat het Unierecht voorrang heeft boven daarmee strijdig nationaal recht. ${ }^{3}$ Voor een particulier is dit onder andere van belang indien het gaat om een bepaling van Unierecht met directe werking, hetgeen betekent dat een particulier zich voor de nationale rechter op deze bepaling kan beroepen. Het bekende voorbeeld is het arrest Van Gend \& Loos, waarin het Hof heeft bepaald dat het huidige art. 30 VWEU directe werking heeft. In dat geval betekende dit dat in een conflict tussen de particulier Van Gend \& Loos en de lidstaat Nederland een nationale wetsbepaling kon worden getoetst aan art. 30 VWEU. ${ }^{4}$

In het arrest Van Gend \& Loos ging het om directe verticale werking van Unierecht; een particulier doet jegens de overheid

3. HvJ EG 15 juli 1964, nr. 6/64 (Costa/ENEL); HvJ EG 9 maart 1978, nr. 106/77 (Simmenthal).

4. HvJ EG 5 februari 1963, nr. 26/62 (Van Gend \& Loos). 


\section{Maandblad \\ Vermogensrecht}

een beroep op een bepaling van Unierecht, ten betoge dat een daarmee strijdige nationale bepaling buiten toepassing dient te worden gelaten. Indien een particulier jegens een andere particulier een beroep kan doen op een bepaling van Unierecht, is er sprake van directe horizontale werking. ${ }^{5}$ Onder directe horizontale werking versta ik het geval dat een regel van Unierecht rechtstreeks de geldigheid, inhoud of uitleg van rechtsverhoudingen tussen particulieren beïnvloedt. ${ }^{6}$

Het is lang onduidelijk geweest of art. 34 en 35 VWEU directe horizontale werking hebben. Het Hof maakte aanvankelijk een onderscheid tussen het vrije verkeer van goederen enerzijds en het vrije verkeer van werknemers, de vrijheid van vestiging en het vrije verkeer van diensten (art. 45, 49 en 56 VWEU) anderzijds. ${ }^{7}$ Het in 2012 gewezen arrest Fra.bo heeft dit onderscheid genuanceerd. ${ }^{8}$

\subsection{Vrij verkeer van werknemers, vrijheid van vestiging en vrij verkeer van diensten}

In het arrest Viking heeft het Hof overwogen dat volgens vaste rechtspraak de verboden besloten in art. 45, 49 en 56 VWEU niet alleen gelden voor handelingen van de overheid, maar ook voor bepalingen van andere aard, strekkende tot collectieve regeling van arbeid in loondienst, zelfstandige arbeid en het verrichten van diensten. ${ }^{9}$ Hieruit mag men volgens het Hof echter niet afleiden dat de directe horizontale werking beperkt is tot particulieren die een regulerende functie hebben of beschikken over een quasiwetgevende bevoegdheid. ${ }^{10}$ Uit de arresten Casteels en Olympique Lyonnais blijkt dat de directe horizontale werking zich uitstrekt tot elke maatregel die, zelfs wanneer hij zonder discriminatie op grond van nationaliteit van toepassing is, het gebruik van de verkeersvrijheden kan belemmeren of minder aantrekkelijk maken. ${ }^{11}$

Het Hof gebruikt drie argumenten ter onderbouwing van deze directe horizontale werking. Ten eerste zijn de verkeersvrijheden fundamentele vrijheden, verankerd in verdragsbepalingen van dwingend recht. ${ }^{12}$ Hiermee duidt het Hof het belang aan van de verkeersvrijheden, in het bijzonder voor de goede werking van de interne markt. ${ }^{13}$ Ten tweede zou de opheffing van de belemmeringen van het vrije verkeer van personen en het vrij verrichten van diensten in gevaar worden gebracht, indien particulieren deze opheffing zouden kunnen neutraliseren. ${ }^{14}$ Particulieren kunnen immers zo machtig zijn

5. Asser/Hartkamp 3-I* 2011, nr. 12.

6. Asser/Hartkamp 3-I* 2011, nr. 12

7. Asser/Hartkamp 3-I* 2011, nr. 57

8. HvJ EU 12 juli 2012, nr. C-171/11 (Fra.bo).

9. HvJ EG 11 december 2007, nr. C-438/05, punt 33 (Viking).

10. HvJ EG 11 december 2007, nr. C-438/05, punt 64-65 (Viking).

11. HvJ EU 10 maart 2011, nr. C-379/09, punt 21-22 (Casteels); HvJ EU 16 maart 2010, nr. C-325/08, punt 33-34 (Olympique Lyonnais). Zie ook M.T. Karayigit, The Horizontal Effect of the Free Movement Provisions, MJ 2011-3, p. 322.

12. HvJ EG 11 december 2007, nr. C-438/05, punt 58 (Viking).

13. Zie met betrekking tot het vrije verkeer van goederen HvJ EG 12 juni 2003, nr. C-112/00, punt 60 (Schmidberger).

14. HvJ EG 11 december 2007, nr. C-438/05, punt 57 (Viking). dat hun acties de facto niet te onderscheiden zijn van overheidsmaatregelen. Ten derde dreigt het gevaar van niet-uniforme toepassing van het Unierecht, zo stelt het Hof. Arbeidsvoorwaarden in de verschillende lidstaten worden nu eens beheerst door wettelijke bepalingen, dan weer door collectieve overeenkomsten en andere rechtshandelingen van privaatrechtelijke aard. Een beperking van de verboden van deze artikelen tot handelingen van de overheid zou kunnen leiden tot het ontstaan van ongelijkheden bij hun toepassing. ${ }^{15}$

In de arresten Angonese en Raccanelli heeft het Hof bepaald dat art. 45 VWEU ook van toepassing is op 'gewone' (overeenkomsten tussen) particulieren. ${ }^{16}$ Het Hof motiveerde zijn oordeel met dezelfde argumenten als ik hiervoor weergaf. Gezien de formuleringen van het Hof geldt dit ook voor art. 49 en 56 VWEU. ${ }^{17}$ Dit blijkt het duidelijkste uit het arrest Viking, waar het Hof art. 45, 49 en 56 VWEU in één adem noemt in de context van directe horizontale werking. ${ }^{18}$

In de arresten Viking en Laval heeft het Hof bepaald dat ook een collectieve actie getoetst kan worden aan art. 49 en 56 VWEU. Een collectieve actie heeft immers tot doel om een collectieve regeling tot stand te brengen, aldus het Hof in het arrest Viking. ${ }^{19}$ Opvallend is dat deze laatste overweging in het arrest Laval ontbreekt, terwijl ook in die zaak de collectieve actie erop was gericht om een collectieve regeling tot stand te brengen. Kennelijk heeft het Hof de directe horizontale werking van art. 45, 49 en 56 VWEU niet op deze wijze willen beperken. ${ }^{20}$ Ook acties zoals die aan de orde waren in de arresten Commissie/Frankrijk en Schmidberger, waarbij het doel niet was om een collectieve regeling tot stand te brengen, kunnen derhalve worden getoetst aan deze artikelen. ${ }^{21}$

\subsection{Vrij verkeer van goederen}

Met betrekking tot overeenkomsten tussen particulieren heeft het Hof in de arresten Sapod en Vlaamse reisbureaus directe horizontale werking van de vrijheid van goederenverkeer van de hand gewezen. ${ }^{22}$ In plaats daarvan dienen overeenkomsten tussen particulieren te worden getoetst aan art. $101 \mathrm{VWEU}$, een mededingingsvoorschrift gericht tot ondernemingen. ${ }^{23}$

In de zaak Fra.bo werd door de verwijzende rechter expliciet de vraag aan de orde gesteld of art. 34 en 35 VWEU directe horizontale werking hebben. ${ }^{24}$ In deze zaak ging het om een Italiaanse producent (Fra.bo) van koperfittingen, die toegang

15. HvJ EG 11 december 2007, nr. C-438/05, punt 34 (Viking).

16. HvJ EG 6 juni 2000, nr. C-281/98, punt 35-36 (Angonese); HvJ EG 17 juli 2008, nr. C-94/07, punt 45 (Raccanelli).

17. Asser/Hartkamp 3-I* 2011, nr. 61.

18. HvJ EG 11 december 2007, nr. C-438/05, punt 33 (Viking).

19. HvJ EG 11 december 2007, nr. C-438/05, punt 36-37 en 60 (Viking).

20. Zie ook Karayigit 2011, p. 324-325.

21. HvJ EG 9 december 1997, nr. C-265/95 (Commissie/Frankrijk); HvJ EG 12 juni 2003, nr. C-112/00 (Schmidberger).

22. HvJ EG 6 juni 2002, nr. C-159/00, punt 74 (Sapod); HvJ EG 1 oktober 1987 , nr. 311/85, punt 30 (Vlaamse reisbureaus).

23. HvJ EG 27 september 1988, nr. 65/85 (Süllhofer).

24. HvJ EU 12 juli 2012, nr. C-171/11 (Fra.bo). 


\section{Maandblad Vermogensrecht}

zocht tot de Duitse markt. Fra.bo liep aan tegen het feit dat het vrijwel onmogelijk was om de Duitse markt te betreden zonder dat de koperfittingen waren gecertificeerd door de privaatrechtelijke organisatie DVGW. Dit kwam met name doordat de Duitse wetgever in een verordening (AVBWasserV) de algemene verkoopvoorwaarden tussen waterleidingbedrijven en hun klanten had geregeld. Hierin was een bepaling opgenomen die erop neerkwam dat een installateur van een waterleiding alleen onderdelen mocht gebruiken die een keurmerk van DVGW hadden. Hoewel partijen vrij waren van die verordening af te wijken, kochten in de praktijk nagenoeg alle Duitse consumenten door DVGW gecertificeerde koperfittingen. Fra.bo raakte in conflict met DVGW en betoogde onder meer dat art. $34 \mathrm{VWEU}$ van toepassing was op DVGW.

In haar conclusie voor het arrest gaat A-G Trstenjak in op de mogelijke directe horizontale werking van de vrijheid van goederenverkeer. Zij stelt voorop dat het Hof zich nog niet heeft uitgesproken over de vraag of ook het vrije verkeer van goederen van toepassing is op collectieve regelingen van nietpubliekrechtelijke aard. ${ }^{25}$ Volgens haar dient het Hof deze vraag bevestigend te beantwoorden. $\mathrm{Zij}$ wijst erop dat het Hof eerdere uitspraken heeft gemotiveerd door te verwijzen naar de gevolgen van deze collectieve regelingen. Het zou daarom onlogisch zijn om de mogelijkheid van directe horizontale werking van het vrije verkeer van goederen categorisch af te wijzen. Er zijn volgens haar geen principiële bezwaren om de argumentatie die het Hof gebruikte in de zaken met betrekking tot art. 39, 45 en 56 VWEU toe te passen op casus waarin het gaat om art. 34 en 35 VWEU. ${ }^{26}$

Het Hof maakt geen vergelijking met art. 39, 45 en 56 VWEU en verwijst ook niet naar de rechtspraak die ik in paragraaf 2.1 heb behandeld. Evenmin verwijst het Hof naar de hiervoor genoemde arresten Sapod, Süllhofer en Vlaamse Reisbureaus. Het Hof overweegt dat de lidstaat Duitsland geen beslissende invloed uitoefent op de activiteiten van DVGW. ${ }^{27}$ Vervolgens onderzoekt het Hof of de activiteit van DVGW het vrije verkeer van goederen belemmert 'op dezelfde wijze als overheidsmaatregelen'. ${ }^{28}$ Het Hof komt tot de conclusie dat dit inderdaad het geval is, omdat de nationale wet de door DVGW goedgekeurde producten als in overeenstemming met het nationale recht beschouwt en dit de verhandeling van nietgekeurde producten bemoeilijkt. ${ }^{29}$ Derhalve kan DVGW feitelijk de toegang tot de markt regelen en is art. $34 \mathrm{VWEU}$ van toepassing op de certificeringsactiviteiten van DVGW.

Het Hof hecht veel waarde aan het bestaan van de verordening AVBWasserV. De vraag is of het Hof anders had geoor-

\footnotetext{
25. Conclusie van A-G Trstenjak van 28 maart 2012, nr. C-171/11, punt 44 (Fra.bo).

26. Deze argumentatie heb ik in par. 2.1 behandeld.

27. HvJ EU 12 juli 2012, nr. C-171/11, punt 24 (Fra.bo).

28. HvJ EU 12 juli 2012, nr. C-171/11, punt 26 (Fra.bo).

29. HvJ EU 12 juli 2012, nr. C-171/11, punt 32 (Fra.bo).
}

deeld indien deze verordening niet had bestaan, maar DVGW op een andere wijze capabel was geweest om de toegang tot de markt te regelen, bijvoorbeeld door haar goede reputatie bij consumenten. Punt 26 en 31 van het arrest bevatten echter algemene formuleringen, waaruit blijkt dat het Hof het bestaan van een wettelijke regeling zoals AVBWasserV niet als voorwaarde ziet voor directe horizontale werking van het vrije verkeer van goederen. ${ }^{30}$

In de arresten Sapod, Süllhofer en Vlaamse reisbureaus beantwoordde het Hof de vraag of art. 34 en 35 VWEU van toepassing zijn op overeenkomsten tussen particulieren. In het arrest Fra.bo ging het om een wezenlijk andere rechtsbetrekking. Dat verklaart mogelijk waarom het Hof niet naar de eerstgenoemde arresten verwijst. Het Hof verwijst in het arrest Fra.bo ook niet naar de jurisprudentie of argumentatie met betrekking tot de directe horizontale werking van art. 39, 45 en 56 VWEU. Men zou daaruit kunnen afleiden dat het Hof (nog steeds) een onderscheid maakt tussen de verschillende verkeersvrijheden.

Toch verschilt de gedachtegang van het Hof in het arrest Fra.bo niet wezenlijk van de gedachtegang in bijvoorbeeld het arrest Viking. Het doel van de vrijverkeerbepalingen is het opheffen van alle maatregelen die het gebruik van de verkeersvrijheden kunnen belemmeren of minder aantrekkelijk kunnen maken. Het is primair de staat die bij machte is dergelijke maatregelen op te leggen. Echter, als een particulier een belemmering kan opwerpen, kunnen de vrijverkeerbepalingen ook op hem van toepassing zijn. ${ }^{31}$ Deze gedachte klinkt onder meer door in zowel het arrest Viking als het arrest Fra.bo. Aldus nuanceert het Hof het onderscheid tussen het vrije verkeer van goederen enerzijds en het vrije verkeer van werknemers, de vrijheid van vestiging en het vrije verkeer van diensten anderzijds. Dat brengt mij tot de conclusie dat ook art. 34 en 35 VWEU directe horizontale werking hebben. ${ }^{32}$

\subsection{Acties van de vakbonden}

De collectieve acties van de vakbonden maken het vervoer van goederen vanuit het ene EU-land naar het andere EU-land via Nederland moeilijk. Zowel de vervoerder als de verzender en de ontvanger van de tegengehouden goederen worden aldus belemmerd in het gebruik van hun recht op vrij verkeer van goederen. De binnenscheepvaart is zo afhankelijk van de sluiswachters, dat de vakbonden door de collectieve acties feitelijk

30. Zie over de interpretatie van het arrest Fra.bo ook N.N. Shuibne, The Treaty Is Coming to Get You..., ELR 2012-4, p. 367; A.S. Hartkamp, European Law and National Private Law, Deventer: Kluwer 2012, nr. 57 en 75 .

31. Zie in gelijke zin Van Harten en Nauta, die weliswaar geen volle erkenning van horizontale directe werking in het arrest lezen, maar dat is volgens hen 'ook nog niet het geval (...) voor de overige fundamentele vrijheden'; H.J. van Harten \& T. Nauta, Nog geen horizontale rechtstreekse werking van het vrije verkeer van goederen?, NTER 2012-10, p. 333-334.

32. De Waele stelt dat door de specifieke omstandigheden van het geval de reikwijdte van het arrest beperkt wordt en dat nog niet van volledige horizontale werking gesproken kan worden; noot De Waele bij HvJ EU 12 juli 2012, nr. C-171/11, JB 2012/96 (Fra.bo). 


\section{Maandblad \\ Vermogensrecht}

het (grensoverschrijdende) goederenvervoer regelen. Aangezien art. 34 en 35 VWEU directe horizontale werking hebben, verzetten deze artikelen zich in beginsel tegen de collectieve acties.

Een belemmering van het vrije verkeer van goederen kan op drie wijzen worden gerechtvaardigd: een verdragsexceptie (art. $36 \mathrm{VWEU}$ ), de rule of reason of een grondrecht. In casu wordt de belemmering mogelijk gerechtvaardigd door een grondrecht, namelijk het recht van collectieve actie. Dit recht is voor het Hof een belangrijk recht, zoals onder meer blijkt uit het arrest Viking: ${ }^{33}$

'77. Het recht om een collectieve actie te voeren die de bescherming van werknemers tot doel heeft, vormt een legitiem belang dat in beginsel een beperking van de door het Verdrag gewaarborgde fundamentele vrijheden kan rechtvaardigen, en de bescherming van werknemers is een van de reeds door het Hof erkende dwingende redenen van algemeen belang.'

Het Hof overweegt vervolgens dat de Unie niet alleen een economisch, maar ook een sociaal doel heeft. ${ }^{34}$ Het recht op collectieve actie die de bescherming van werknemers tot doel heeft, rechtvaardigt een beperking van het vrije verkeer van goederen indien aan de volgende vereisten is voldaan: ${ }^{35}$

1. De collectieve actie is geschikt om dit doel te verwezenlijken (geschiktheid).

2. De collectieve actie gaat niet verder dan noodzakelijk is om het doel te bereiken (noodzakelijkheid).

3. Er is een redelijke afweging gemaakt tussen de verschillende belangen (evenredigheid in strikte zin).

Volgens het Hof staat vast dat een collectieve actie voor vakbonden een van de voornaamste middelen kan zijn om de belangen van hun leden te beschermen. ${ }^{36}$ De staking is in casu een geschikt middel, omdat op die manier de werkgever, in casu Rijkswaterstaat, extra onder druk kan worden gezet (vereiste 1). Een staking is het ultimum remedium van een vakbond om zijn eisen kracht bij te zetten. Voor de casus ga ik ervan uit dat de vakbonden alle andere middelen, zoals onderhandelen, hebben uitgeput. Dat makt de staking in casu noodzakelijk (vereiste 2). Men kan zich echter afvragen of er een redelijke afweging is gemaakt tussen de verschillende belangen. Er worden gigantische hoeveelheden goederen vervoerd per schip. Het belang van de werknemers weegt wellicht

33. HvJ EG 11 december 2007, nr. C-438/05, punt 77 (Viking); zie ook HvJ EG 18 december 2007, nr. C-341/05, punt 103 (Laval).

34. HvJ EG 11 december 2007, nr. C-438/05, punt 78 en 79 (Viking); HvJ EG 18 december 2007, nr. C-341/05, punt 104 en 105 (Laval).

35. HvJ EG 11 december 2007, nr. C-438/05, punt 80 en 84 (Viking); J.H. Gerards, Het evenredigheidsbeginsel van art. 3:4 lid 2 Awb en het Europese recht, in: T. Barkhuysen, W. den Ouden \& E. Steyger (red.), Europees recht effectueren. Algemeen bestuursrecht als instrument voor de effectieve uitvoering van EG-recht, Alphen aan den Rijn: Kluwer 2007, p. 76.

36. HvJ EG 11 december 2007, nr. C-438/05, punt 86 (Viking). niet op tegen het belang van degenen die de goederen vervoeren, hebben verzonden of moeten ontvangen (vereiste 3 ).

Voor de casus ga ik ervan uit dat de vakbonden er niet in slagen om aan te tonen dat de staking voldoet aan het derde vereiste. In dat geval vormt het recht op collectieve actie geen rechtvaardiging voor de belemmering van het vrije verkeer van goederen en verzet het Unierecht zich dus tegen de acties van de vakbonden.

\section{Gevolgen van directe horizontale werking}

In deze paragraaf behandel ik de mogelijke privaatrechtelijke gevolgen van het feit dat het Unierecht zich verzet tegen de acties van de vakbonden. Meer specifiek zal ik de volgende vragen beantwoorden:

1. Is de afspraak tussen de vakbonden om te gaan staken nietig?

2. Hebben de ladingbelanghebbenden een recht op schadevergoeding?

3. Dient de rechter de nietigheid van de afspraak tussen de vakbonden ambtshalve te beoordelen, indien door partijen op de nietigheid geen beroep is gedaan?

\subsection{Nietigheid van de afspraak}

De drie vakbonden hebben zich jegens elkaar verbonden om te gaan staken. Naar Nederlands recht is deze afspraak een overeenkomst in de zin van art. 6:213 van het Burgerlijk Wetboek (BW). Deze overeenkomst kan nietig zijn op grond van het Unierecht. Art. 101 lid 2 VWEU bepaalt dat verboden overeenkomsten of besluiten in de zin van dat artikel van rechtswege nietig zijn. De Commissie heeft echter in een bekendmaking bepaald dat de sociale takk van een vakbond aan te merken is als een niet-economische taak. ${ }^{37}$ In casu oefenen de vakbonden hun sociale taak uit. Dit betekent dat de vakbonden - in deze hoedanigheid - niet zijn aan te merken als ondernemingen in de zin van art. $101 \mathrm{VWEU}$, en dat de overeenkomst daarom buiten de werkingssfeer van laatstgenoemd artikel valt. ${ }^{38}$

Het VWEU bevat geen bepalingen die de privaatrechtelijke rechtsgevolgen regelen van een schending van andere regels van Unierecht met directe horizontale werking. In dat geval is het aan het Hof om de rechtsgevolgen te regelen. ${ }^{39}$ Het Hof heeft nog niet geoordeeld dat een rechtshandeling in strijd is met art. 34 en 35 VWEU. Ook over de rechtsgevolgen van een rechtshandeling die in strijd is met art. 45, 49 en $56 \mathrm{VWEU}$ heeft het Hof zich niet concreet uitgelaten. ${ }^{40}$ Kennelijk laat het Hof de gevolgen over aan het nationale recht. Volgens

37. Bekendmaking Commissie, PbEG 2001, C-17/04, punt 30.

38. Zie in dit verband ook het arrest Albany, waarin het Hof heeft bepaald dat een overeenkomst wegens haar aard en doel buiten de werkingssfeer van art. 101 VWEU kan vallen, en dat dit het geval is bij een collectieve arbeidsovereenkomst die een aanvullende pensioenregeling voor een bedrijfstak regelt; HvJ EG 21 september 1999, nr. C-67/96, punt 59-64 (Albany).

39. Asser/Hartkamp 3-I* 2011, nr. 13.

40. Asser/Hartkamp 3-I* 2011, nr. 61. 
Hartkamp vloeit in dat geval naar Nederlands recht de nietigheid van de rechtshandeling voort uit art. 3:40 lid 2 BW, omdat het Unierecht zich verzet tegen het verrichten van de rechtshandeling. ${ }^{41}$

Vaak zal echter niet de overeenkomst zelf in strijd met het Unierecht zijn, maar de prestatie waartoe de overeenkomst verplicht. In dat geval is de overeenkomst mogelijk in strijd met de openbare orde en dus nietig op grond van art. 3:40 lid 1 BW..$^{42}$ De Hoge Raad heeft in het arrest Esmilo/Mediq geoordeeld dat de enkele omstandigheid dat een overeenkomst tot een door de wet verboden prestatie verplicht, niet meebrengt dat de overeenkomst in strijd met de openbare orde is, en dus nietig is. ${ }^{43}$ De rechter dient bij zijn beoordeling in elk geval gemotiveerd te betrekken welke belangen door de geschonden regel worden beschermd, of door de inbreuk op de regel fundamentele beginselen worden geschonden, of partijen zich van de inbreuk op de regel bewust waren, en of de regel in een sanctie voorziet.

Een andere mogelijkheid die tot nietigheid van de overeenkomst kan leiden, is de doorwerking van Unierecht via open normen. De Nederlandse rechter kan art. 3:40 lid 1 BW Unierechtconform interpreteren, in de zin dat een rechtshandeling die in strijd is met een bepaling van Unierecht strijdig is met de openbare orde of goede zeden. Deze indirecte horizontale werking van het Unierecht is met name relevant indien een bepaling van Unierecht geen directe horizontale werking heeft. ${ }^{44}$

Uit paragraaf 2 blijkt dat de collectieve acties van de vakbonden een belemmering vormen van het vrije verkeer van goederen die niet wordt gerechtvaardigd door het recht op collectieve actie. Aldus verzet het Unierecht zich tegen de feitelijke handeling van de vakbonden. Dat betekent dat in casu de overeenkomst tussen de vakbonden verplicht tot een verboden prestatie. Dat heeft tot gevolg dat de inhoud of strekking van de overeenkomst mogelijk in strijd is met de openbare orde, en dus nietig is op grond van art. 3:40 lid $1 \mathrm{BW}$. Of dat het geval is, dient men te beoordelen aan de hand van de criteria uit het hiervoor genoemde arrest Esmilo/Mediq. Het vrije verkeer van goederen is een fundamentele vrijheid, die mede bestemd is om een interne markt tot stand te brengen en de werking daarvan te verzekeren. ${ }^{45}$ Hoewel de vakbonden zich niet bewust waren van de inbreuk op deze regel, en art. 34 en 35

41. A.S. Hartkamp, De werking van het EG-Verdrag in privaatrechtelijke verhoudingen. Opmerkingen over directe en indirecte horizontale werking van het primaire gemeenschapsrecht, WPNR (2009) 6792, punt 3.

42. Asser/Hartkamp \& Sieburgh 6-III*, Deventer: Kluwer 2010, nrs. 317 en 325.

43. HR 1 juni 2012, ECLI:NL:HR:2012:BU5609, r.o. 4.4 (Esmilo/Mediq); vgl. in die zin reeds Asser/Hartkamp \& Sieburgh 6-III* 2010, nr. 325.

44. De rechter heeft ook de mogelijkheid om art. 6:248 lid 2 BW Unierechtconform te interpreteren, en het beding uit de overeenkomst op die grond buiten toepassing te laten. Deze mogelijkheid brengt echter niet de nietigheid van de overeenkomst met zich; Asser/Hartkamp 3-I* 2011, nr. 95.

45. Zie art. 26 VWEU.
VWEU niet in een sanctie voorzien, brengt dit mijns inziens met zich dat de inhoud van de overeenkomst tussen de vakbonden in strijd is met de openbare orde en de overeenkomst dus nietig is op grond van art. 3:40 lid $1 \mathrm{BW}$.

\subsection{Recht op schadevergoeding}

De ladingbelanghebbenden kunnen een recht op schadevergoeding hebben jegens de vakbonden. Men kan daarbij denken aan degenen van wie de goederen afkomstig zijn, voor wie de goederen bestemd zijn of die de goederen hadden moeten vervoeren.

Het Hof heeft de in het Unierecht verankerde niet-contractuele aansprakelijkheid van particulieren aangenomen in de arresten Otis, Manfredi en Courage/Crehan. ${ }^{46}$ In deze arresten ging het om een schending van art. 101 VWEU. Het Hof heeft overwogen dat aan de volle werking van art. 101 VWEU afbreuk zou worden gedaan indien niet eenieder vergoeding zou kunnen vorderen van de schade die hem is berokkend door een overeenkomst of een gedraging die de mededinging kan beperken of vervalsen. ${ }^{47}$ Een dergelijk recht maakt de mededingingsregels van de Unie immers gemakkelijker toepasbaar en zorgt ervoor dat - vaak heimelijke - overeenkomsten of praktijken die de mededinging kunnen beperken of vervalsen, minder aantrekkelijk worden. ${ }^{48}$

Deze redenering kan analoog worden toegepast op andere regels van Unierecht met directe horizontale werking. ${ }^{49}$ Ook voor een schending van bijvoorbeeld art. 34 en 35 VWEU geldt immers dat aan de volle werking van deze bepalingen afbreuk zou worden gedaan indien niet eenieder die door een schending schade heeft geleden, vergoeding zou kunnen vorderen. Sieburgh komt op grond van de rechtspraak van het Hof tot de volgende drie vereisten voor aansprakelijkheid van een particulier (jegens een andere particulier): ${ }^{50}$

46. HvJ EU 6 november 2012, nr. C-199/11 (Otis); HvJ EG 13 juli 2006, nr. C-295/04 t/m C-298/04 (Manfredi); HvJ EG 20 september 2001, nr. C-43/99 (Courage/Crehan).

47. HvJ EU 6 november 2012, nr. C-199/11, punt 41 (Otis); HvJ EG 13 juli 2006, nr. C-295/04 t/m C-298/04, punt 60 (Manfredi); HvJ EG 20 september 2001, nr. C-43/99, punt 26 (Courage/Crehan).

48. HvJ EU 6 november 2012, nr. C-199/11, punt 42 (Otis); HvJ EG 13 juli 2006, nr. C-295/04 t/m C-298/04, punt 91 (Manfredi); HvJ EG 20 september 2001, nr. C-43/99, punt 27 (Courage/Crehan).

49. C.H. Sieburgh, Het Europese gemeenschapsrecht en het Nederlandse buiten-contractuele aansprakelijkheidsrecht, in: A.S. Hartkamp, C.H. Sieburgh \& L.A.D. Keus (red.), De invloed van het Europese recht op het Nederlandse privaatrecht (Serie Onderneming en Recht, deel 42-I), Deventer: Kluwer 2007, p. 517; S. Drake, Scope of Courage and the Principle of 'Individual Liability' for Damages: Further Development of the Principle of Effective Judicial Protection by the Court of Justice, ELR 2006, p. 858.

50. Sieburgh 2007, p. 522; Zie ook T. Trimidas, The General Principles of EU Law, Oxford: Oxford University Press 2006, p. 544. 
1. Een regel van Unierecht is geschonden (een gekwalificeerde schending is niet vereist $) .51$

2. De geschonden regel moet ertoe strekken rechten toe te kennen aan particulieren.

3. Er bestaat een direct causaal verband tussen de geleden schade en de schending.

Het causaal verband en de omvang van de schade dienen te worden beoordeeld aan de hand van nationaal recht, omdat vooralsnog Unierechtelijke regels ontbreken, afgezien van de eisen van doeltreffendheid en gelijkwaardigheid. ${ }^{52}$

Naar Nederlands recht kan men een recht op schadevergoeding ontlenen aan art. 6:162 BW. Onder de zinsnede wettelijke plicht uit art. 6:162 lid 2 BW valt ook een regel van Unierecht die directe horizontale werking heeft. ${ }^{53}$ Dat betekent dat het Nederlandse recht als onrechtmatige daad aanmerkt handelen in strijd met een bepaling van Unierecht met directe horizontale werking. Indien aan alle overige vereisten uit art. 6:162 en 6:163 BW is voldaan, hebben de ladingbelanghebbenden een recht op schadevergoeding jegens de vakbonden.

Een andere mogelijkheid die tot een recht op schadevergoeding kan leiden, is de doorwerking van Unierecht via open normen. De Nederlandse rechter kan art. 6:162 BW Unierechtconform interpreteren, in de zin dat een handeling die in strijd is met een bepaling van Unierecht in strijd is met hetgeen volgens ongeschreven recht in het maatschappelijk verkeer betaamt. Deze indirecte horizontale werking van Unierecht is met name relevant indien een bepaling van Unierecht geen directe horizontale werking heeft.

Uit paragraaf 2 blijkt dat de collectieve acties van de vakbonden een belemmering vormen van het vrije verkeer van goederen, die niet wordt gerechtvaardigd door het recht op collectieve actie. Aldus verzet het Unierecht zich tegen de feitelijke handeling van de vakbonden. Dat betekent dat de ladingbelanghebbenden een recht op schadevergoeding kunnen ontlenen aan het Unierecht indien aan de drie hiervoor genoemde vereisten is voldaan.

Art. 34 en 35 VWEU verzetten zich tegen de collectieve acties van de vakbonden. Derhalve is er sprake van een schending van een regel van Unierecht (vereiste 1). Uit de directe horizontale werking van art. 34 en 35 VWEU volgt dat deze artikelen ertoe strekt rechten toe te kennen aan particulieren (ver-

51. In onder meer het arrest Dillenkofer stelt het Hof als een van de voorwaarden voor de aansprakelijkheid van een lidstaat jegens een particulier, de omstandigheid dat er sprake is van een gekwalificeerde schending van een regel van Unierecht. In de hiervoor genoemde arresten Courage/ Crehan, Manfredi en Otis stelt het Hof deze voorwaarde niet voor de aansprakelijkheid van een particulier jegens een andere particulier wegens schending van art. 101 VWEU. HvJ EG 8 oktober 1996, nr. C-178/94, C-179/94, C-188/94, C-189/94 en C-190/94, punt 21 (Dillenkofer).

52. Sieburgh 2007, p. 523.

53. Asser/Hartkamp \& Sieburgh 6-IV*, Deventer: Kluwer 2011, nr. 44. eiste 2). ${ }^{54}$ Het causaal verband en de geleden schade dienen te worden beoordeeld naar Nederlands recht (vereiste 3 ). Indien ook aan deze vereisten is voldaan, hebben de ladingbelanghebbenden op grond van Unierecht een recht op schadevergoeding jegens de vakbonden.

Mogelijk hebben de ladingbelanghebbenden ook een recht op schadevergoeding op grond van het Nederlandse recht. Omdat art. 34 en 35 VWEU directe horizontale werking hebben, handelen de vakbonden in strijd met een wettelijke plicht in de zin van art. 6:162 lid 2 BW. Dit levert een onrechtmatige daad op. Indien ook aan alle overige vereisten uit art. 6:162 en 6:163 BW is voldaan, hebben de ladingbelanghebbenden op grond van het Nederlandse recht een recht op schadevergoeding jegens de vakbonden.

\subsection{Ambtshalve toepassing}

Stel dat vakbond A de overeenkomst niet nakomt, en vakbonden $\mathrm{B}$ en $\mathrm{C}$ vakbond $\mathrm{A}$ in rechte aanspreken tot nakoming. Vakbond A doet geen beroep op de nietigheid van de overeenkomst, maar verweert zich door te stellen dat de afspraak die hij met B en C heeft gemaakt slechts vrijblijvend was. De rechter kan in dat geval verplicht zijn ambtshalve de nietigheid van de overeenkomst te beoordelen. ${ }^{55}$

De plicht tot ambtshalve toepassing in de zin dat de rechter verplicht is ambtshalve een overeenkomst tussen twee particulieren te toetsen aan een bepaling van Unierecht is alleen aan de orde indien de desbetreffende bepaling directe horizontale werking heeft. ${ }^{56}$ Hartkamp noemt zes gronden waarop de Unierechtelijke verplichting tot ambtshalve toepassing van Unierecht kan berusten: ${ }^{57}$

1. het doeltreffendheidsbeginsel;

2. het gelijkwaardigheidsbeginsel;

3. het aangescherpte gelijkwaardigheidsbeginsel;

4. een door het Hof aan een regel(ing) gegeven uitleg die inhoudt dat de regeling of bepaalde regels daarvan naar inhoud of strekking ambtshalve moeten worden toegepast;

5. een bepaling of rechterlijke interpretatie waaruit valt af te leiden dat een regel van Unierecht van openbare orde is;

6. een uitdrukkelijk wettelijk voorschrift. ${ }^{58}$

54. Het recht op schadevergoeding kan ook worden afgeleid uit een regel die een verbod oplegt en daaraan inherent een plicht in het leven roept. In casu betreft het dan het verbod op belemmeringen van het vrije verkeer van goederen; Sieburgh 2007, p. 525.

55. In het navolgende bedoel ik met ambtshalve toepassing of aanvulling ambtshalve toepassing of aanvulling buiten de grenzen van de rechtsstrijd.

56. A.S. Hartkamp, De verplichting tot ambtshalve toepassing van Europees recht door de Nederlandse rechter, Trema 2010, p. 141; een richtlijn heeft geen directe horizontale werking. Bij de ambtshalve toetsing van oneerlijke bedingen in het licht van art. 6 van Richtlijn 93/13/EEG toetst de rechter dus niet aan dit artikel, maar aan de implementatiewetgeving. In het geval van Nederland is dat art. 6:233 sub a BW. Zie ook A.S. Hartkamp, Ambtshalve aanvulling van rechtsgronden naar Europees recht en naar Nederlands recht, Deventer: Kluwer 2007, p. 26, noot 44.

57. Hartkamp 2010, p. 136-137.

58. Aangezien dergelijke voorschriften niet bestaan, laat ik deze grond verder buiten beschouwing. Zie Hartkamp 2010, p. 136. 


\section{Maandblad Vermogensrecht}

Bij het ontbreken van een Unierechtelijke regeling omtrent ambtshalve toepassing van een bepaling is het aan de rechtsorde van de lidstaten om de toepasselijke procesregels te geven. Deze regels mogen echter niet ongunstiger zijn dan die welke voor soortgelijke nationale vorderingen gelden (gelijkwaardigheidsbeginsel), en zij mogen de uitoefening van de door het Unierecht verleende rechten in de praktijk niet onmogelijk of uiterst moeilijk maken (doeltreffendheidsbeginsel). ${ }^{59}$

Ten aanzien van Richtlijn 93/13/EEG ${ }^{60}$ en waarschijnlijk ook art. $101 \mathrm{VWEU}$ is er wel een Unierechtelijke regeling die betrekking heeft op ambtshalve toepassing van het Unierecht, en wel door uitspraken van het Hof. De verplichting tot ambtshalve toepassing van (de implementatiewetgeving voortvloeiend uit) Richtlijn 93/13/EEG berust op de door het Hof gegeven uitleg van de richtlijn. ${ }^{61}$ Voor art. $101 \mathrm{VWEU}$ geldt dat de nationale rechter dit artikel ambtshalve dient toe te passen omdat dit een bepaling van Unierechtelijke openbare orde is. $^{62}$

Het Hof is nog niet in de gelegenheid geweest tot beantwoording van de vraag of er ook een Unierechtelijke regeling bestaat ten aanzien van de ambtshalve toepassing van de vrijverkeerbepalingen, in het bijzonder het vrije verkeer van goederen. Het is wellicht mogelijk om op grond van de rechtspraaklijn met betrekking tot art. 101 VWEU tot een antwoord te komen op de vraag of de nationale rechter art. 34 en 35 VWEU ambtshalve dient toe te passen. ${ }^{63}$

De vraag of de nationale rechter art. 101 VWEU ambtshalve dient toe te passen, kwam als eerst aan de orde in het arrest Van Schijndel. In dit arrest, waar het niet ging om de toetsing van rechtshandelingen, beantwoordde het Hof de vraag ontkennend met behulp van het gelijkwaardigheidsbeginsel en het doeltreffendheidsbeginsel.

In de arresten T-Mobile en Manfredi heeft het Hof onder verwijzing naar het arrest Eco Swiss overwogen dat art. 101 VWEU een bepaling van openbare orde is die door de natio-

59. HvJ EG 7 juni 2007, nr. C-222/05 t/m C-225/05, punt 29 (Van der Weerd); HvJ EG 14 december 1995, nr. C-430/93 en C-431/93, punt 17 (Van Schijndel).

60. Richtlijn 93/13/EEG van de Raad van 5 april 1993 betreffende oneerlijke bedingen in consumentenovereenkomsten, PbEG 1993, L 95, p. 29-34; art. 6 van deze richtlijn legt de lidstaten de plicht op ervoor te zorgen dat oneerlijke bedingen de consument niet binden.

61. Dit is grond 4 van de zes door Hartkamp geschetste gronden. Zie voor dit leerstuk ook A.G.F. Ancery, Ambtshalve toepassing van consumentenbeschermend EU-recht, MvV 2013-12.

62. Dit is grond 5 van de zes door Hartkamp geschetste gronden.

63. Naar mijn mening is de rechtspraaklijn met betrekking tot Richtlijn 93/13/EEG niet relevant voor de vraag of de nationale rechter de vrijverkeerbepalingen ambtshalve dient toe te passen. In deze rechtspraaklijn acht het Hof de situatie van ongelijkheid tussen verkoper en consument een belangrijk element om te komen tot de plicht tot ambtshalve toepassing. In het geval van een belemmering van een verkeersvrijheid is echter niet op voorhand sprake van een situatie van ongelijkheid van partijen. nale rechter ambtshalve moet worden toegepast. ${ }^{64}$ Hoe het Hof daartoe is gekomen, volgt uit het arrest Eco Swiss: ${ }^{65}$

'36. In overeenstemming met artikel 3, sub g, EG-Verdrag vormt artikel 85 [huidig art. $101 \mathrm{VWEU}$; TSH] van het Verdrag evenwel een fundamentele bepaling die onontbeerlijk is voor de vervulling van de taken van de Gemeenschap en in het bijzonder voor de werking van de interne markt. Het belang van deze bepaling heeft de opstellers van het Verdrag ertoe gebracht, in artikel 85, lid 2 [huidig art. 101 lid 2 VWEU; TSH], uitdrukkelijk te bepalen, dat de door dit artikel verboden overeenkomsten of besluiten van rechtswege nietig zijn.'

Het Hof acht art. 101 VWEU onontbeerlijk voor de taken van de Europese Unie, in het bijzonder voor de werking van de interne markt. Daarbij verwijst het Hof naar art. 3 van het inmiddels niet meer van kracht zijnde EG-Verdrag, waarin de doelstellingen van de Europese Unie nader worden omschreven. Onder c van dit artikel wordt ook specifiek het afschaffen van hinderpalen voor het vrije verkeer van goederen, personen, diensten en kapitaal genoemd. Daarnaast noemt het Hof art. 101 VWEU een fundamentele bepaling. Een gelijke kwalificatie gebruikt het Hof ten aanzien van de vrijverkeerbepalingen, door deze fundamentele vrijheden te noemen. ${ }^{66}$

Hoewel het VWEU ten aanzien van het vrije verkeer van goederen geen equivalent van art. 101 lid 2 VWEU bevat, zijn ook art. 34 en 35 VWEU fundamentele bepalingen die onontbeerlijk zijn voor de vervulling van de taken van de Unie, in het bijzonder voor de werking van de interne markt. Daarnaast hebben deze bepalingen ook directe horizontale werking. Hetgeen het Hof heeft overwogen met betrekking tot de plicht tot ambtshalve toepassing van art. 101 VWEU geldt dus eveneens voor art. 34 en 35 VWEU. ${ }^{67}$

64. HvJ EG 4 juni 2009, nr. C-8/08, punt 49 (T-Mobile); HvJ EG 13 juli 2006, nr. C-295/04 t/m C-298/04, punt 31 (Manfredi).

65. HvJ EG 1 juni 1999, nr. C-126/97, punt 36 (Eco Swiss); zie in soortgelijke bewoordingen ook HvJ EG 4 juni 2009, nr. C-8/08, punt 49 (T-Mobile). Art. 3 lid 1 EG-Verdrag is niet meer in deze vorm terug te vinden in het Verdrag betreffende de Europese Unie (VEU) of het VWEU, maar is ten gronde vervangen door art. $3 \mathrm{VEU}$.

66. HvJ EG 11 december 2007, nr. C-438/05, punt 59 (Viking); HvJ EG 6 juni 2000, nr. C-281/98, punt 35 (Angonese).

67. Zie ook R. Barents \& L.J. Brinkhorst, Grondlijnen van Europees recht, Deventer: Kluwer 2012, nr. 565 en 853; Hartkamp 2010, p. 143. 


\section{Maandblad \\ Vermogensrecht}

In de literatuur bestaat discussie over de interpretatie van de arresten Eco Swiss, Manfredi en T-Mobile. ${ }^{6}$ De Hoge Raad lijkt in het arrest Vreugdenhil, waarin het ging om de toetsing van een overeenkomst aan art. 101 VWEU, impliciet van mening te zijn dat art. $101 \mathrm{VWEU}$ een regel van openbare orde is, die de rechter buiten de grenzen van de rechtsstrijd dient toe te passen. ${ }^{69}$ In het latere arrest Heerlen/Whizz gaat de Hoge Raad de vraag uit de weg of art. 101 VWEU recht van openbare orde bevat. ${ }^{70} \mathrm{Om}$ aan alle rechtsonzekerheid een eind te maken, heeft het Gerechtshof Amsterdam aan het Hof de prejudiciële vraag voorgelegd of art. 101 VWEU een bepaling van openbare orde is die meebrengt dat de rechter deze bepaling ambtshalve moet toepassen buiten de grenzen van de rechtsstrijd. ${ }^{71}$ In zijn conclusie komt A-G Cruz Villalón niet aan beantwoording van de vraag toe. ${ }^{72}$ Het Hof heeft op het moment van schrijven nog geen uitspraak gedaan.

68. Hartkamp stelt dat men uit de jurisprudentie kan afleiden dat art. 101 VWEU van openbare orde is en om die reden ambtshalve moet worden toegepast. Ook Barents, Ottervanger en Van Aerde zijn die mening toegedaan. Onder anderen Snijders, Mok, Keus en Zippro spreken dit tegen. Hartkamp beperkt naar eigen zeggen de duiding van alle arresten tot de berechte casuspositie en stelt dat de arresten Van der Weerd en Van Schijndel zich niet verzetten tegen ambtshalve toepassing in andere gevallen. In het bijzonder noemt hij het geval dat een overeenkomst in strijd is met art. 101 VWEU. Mok stelt in zijn noot bij het arrest T-Mobile dat hij niet begrijpt hoe het Hof tot de hiervoor geciteerde rechtsoverweging is gekomen. Hij verwijst daarbij naar het arrest Van der Weerd. Hij sluit echter niet uit dat de 'horloges binnen het Hof niet geheel gelijk lopen'. Keus kent ook algemene betekenis toe aan het arrest Van der Weerd in zijn conclusie voor het arrest Heerlen/Whizz. Hierbij zij opgemerkt dat Keus geen rekening kon houden met het arrest T-Mobile, omdat dat op dat moment nog niet gewezen was. In een later geschrift (Mon. BW A30) merkt Keus het arrest T-Mobile wel op, maar verbindt daar geen conclusies aan. Snijders stelt de leer van Van Schijndel voorop. Hij is van mening dat art. 101 VWEU niet van openbare orde is in de zin dat de rechter dit artikel ambtshalve buiten de grenzen van de rechtsstrijd dient toe te passen, maar wel in andere zin van openbare orde is. Dit leidt hij af uit het arrest Eco Swiss, waarin het Hof heeft bepaald dat art. 101 VWEU van openbare orde is in de zin van het Executieverdrag van New York. Snijders stelt dat de arresten Manfredi en T-Mobile dit onderscheid miskennen en blijft dan ook bij zijn standpunt dat art. 101 VWEU niet van openbare orde is, in de zin dat de rechter deze bepaling ambtshalve dient toe te passen buiten de grenzen van de rechtsstrijd. Zippro volgt Snijders. Barents \& Brinkhorst 2012, nr. 565; T.R. Ottervanger, Handhaving van het mededingingsrecht: een hete herfst?, M\&M 2009-5, p. 135; A.M. van Aerde, Europees recht en het stelsel van art. 24 en 25 Rv, MvV 2009-6, p. 137; Hartkamp 2010, p. 142; noot Mok bij HvJ EG 4 juni 2009, nr. C-8/08, NJ 2009/432 (T-Mobile); conclusie van A-G Keus voor HR 16 januari 2009, NJ 2009/54, punt 2.9 (Gemeente Heerlen/Whizz); conclusie van A-G Keus voor HR 3 december 2004, NJ 2005/118, punt 2.8 (Vreugdenhil); L.A.D. Keus, Europees Privaatrecht (Mon. BW A30), Deventer: Kluwer 2010, p. 68; H.J. Snijders, Andermaal de vraag naar ambtshalve aanvulling van rechtsgronden (van Europees recht), een reactie op A.S. Hartkamp, WPNR (2009) 6813 en een korte bespreking van het Asturcom-arrest, WPNR (2009) 6823, p. 1000; E.-J. Zippro, Privaatrechtelijke handhaving van het mededingingsrecht, Deventer: Kluwer 2009, p. 270-272.

69. HR 3 december 2004, NJ 2005/118, r.o. 3.6 (Vreugdenhil); Snijders en Zippro achten deze uitspraak onjuist; H.J. Snijders, Ambtshalve aanvulling van gronden van Europees recht in burgerlijke zaken herijkt, WPNR (2008) 6761, p. 544. Zippro 2009, p. 253-254.

70. HR 16 januari 2009, NJ 2009/54, r.o. 3.3 (Gemeente Heerlen/Whizz).

71. Hof Amsterdam 4 oktober 2011, ECLI:NL:GHAMS:2011:BT6548, punt 3 sub V.

72. Conclusie van A-G Cruz Villalón van 30 april 2013, nr. C-518/11, punt 59.
Wat mij betreft is de jurisprudentie van het Hof helder: het arrest T-Mobile is geen fout en art. $101 \mathrm{VWEU}$ is van Unierechtelijke openbare orde. Omdat de argumenten die het Hof gebruikt om tot dit oordeel te komen ook gelden voor art. 34 en 35 VWEU, zijn ook deze artikelen van Unierechtelijke openbare orde. Derhalve dient de nationale rechter ook deze bepalingen ambtshalve toe te passen. $\mathrm{Bij}$ toepassing van de door het Hof gekozen benadering in het arrest Pannon ontstaat de plicht tot ambtshalve toepassing wanneer de rechter beschikt over de noodzakelijke gegevens, feitelijk en rechtens. $^{73}$

Dat betekent in casu dat de rechter verplicht is ambtshalve de overeenkomst tussen de vakbonden te toetsen aan art. 34 en 35 VWEU, ook indien vakbond A geen beroep doet op de nietigheid van de overeenkomst. Deze verplichting komt op de rechter te rusten, zodra hij beschikt over de noodzakelijke gegevens. In het bijzonder dient de inhoud van de overeenkomst tussen de vakbonden bij de rechter bekend te zijn.

\section{Slotsom}

Het feit dat de verdragsbepalingen betreffende het vrije verkeer van goederen zich verzetten tegen de collectieve acties van de vakbonden, heeft de volgende gevolgen: ${ }^{74}$

1. De afspraak tussen de vakbonden is nietig op grond van art. 3:40 lid 1 BW.

2. De ladingbelanghebbenden hebben zowel op grond van het Unierecht als op grond van het Nederlandse recht een recht op schadevergoeding jegens de vakbonden.

3. Op grond van het Unierecht dient de nationale rechter ambtshalve de afspraak tussen de vakbonden te toetsen aan art. 34 en 35 VWEU, ook indien vakbond A geen beroep doet op de nietigheid van de afspraak.

In deze bijdrage heb ik voor een specifieke casus aangetoond hoe het Unierecht privaatrechtelijke rechtsverhoudingen kan beïnvloeden. Met de theorie uit het Asserdeel 3-I* en de behandeling van de toepassing van deze theorie in deze bijdrage is het voor de praktijkjurist mogelijk om te bepalen wat de invloed is van andere bepalingen van Unierecht op privaatrechtelijke rechtsverhoudingen in andere casus.

Bij de bepaling daarvan is het belangrijk om het volgende in het achterhoofd te houden. De Europese Unie heeft zichzelf doelstellingen opgelegd, waaronder het tot stand brengen van een interne markt en het beschermen van consumenten. ${ }^{75} \mathrm{Om}$ die doelstellingen te bereiken bevat het Unierecht vele bepalingen die primair gericht zijn tot de lidstaten. De volle werking daarvan kan echter in gevaar komen indien particulieren categorisch uitgesloten zijn van binding aan deze bepalingen.

73. Vgl. HvJ EG 4 juni 2009, nr. C-243/08, punt 32 (Pannon).

74. Zoals in de inleiding al naar voren kwam, heb ik in deze bijdrage ook geprobeerd aan te geven hoe de rechtspraak van het Hof zich zal gaan ontwikkelen. Daarbij gaat het dus niet altijd om de huidige stand van de rechtspraak.

75. Zie art. 3 lid 3 VEU en art. 169 lid 1 VWEU. 


\section{Maandblad}

Het Hof deinst er daarom niet voor terug om een bepaling van Unierecht ook op particulieren van toepassing te verklaren, indien zij capabel zijn om het bereiken van een doelstelling van de Europese Unie te verhinderen. Dat betekent dat de desbetreffende bepaling rechtstreeks de geldigheid, inhoud of uitleg van rechtsverhoudingen tussen particulieren kan beïnvloeden. Voorbeelden daarvan heb ik in deze bijdrage beschreven: de nietigheid van een rechtshandeling of het recht op schadevergoeding jegens een particulier. Daarnaast kan dat betekenen dat de nationale rechter de plicht heeft om de desbetreffende bepaling van Unierecht ambtshalve buiten de grenzen van de rechtsstrijd toe te passen. 